University of Nebraska - Lincoln

DigitalCommons@University of Nebraska - Lincoln

Mammalogy Papers: University of Nebraska

State Museum

Museum, University of Nebraska State

November 1970

\title{
Additional Notes an Some Mammals From Eastern Nebraska
}

Hugh H. Genoways

University of Kansas, Lawrence, h.h.genoways@gmail.com

Jerry R. Choate

University of Kansas, Lawrence

Follow this and additional works at: https://digitalcommons.unl.edu/museummammalogy

Part of the Zoology Commons

Genoways, Hugh H. and Choate, Jerry R., "Additional Notes an Some Mammals From Eastern Nebraska" (1970). Mammalogy Papers: University of Nebraska State Museum. 63.

https://digitalcommons.unl.edu/museummammalogy/63

This Article is brought to you for free and open access by the Museum, University of Nebraska State at DigitalCommons@University of Nebraska - Lincoln. It has been accepted for inclusion in Mammalogy Papers: University of Nebraska State Museum by an authorized administrator of DigitalCommons@University of Nebraska Lincoln. 


\title{
Short Notes
}

\section{Additional Notes on Some Mammals From Eastern Nebraska}

\author{
HUGH H. GENOWAYS and JERRY R. CHOATE
}

Museum of Natural History, The University of Kansas, Lawrence 66044

Field studies concerned primarily with distribution of the short-tailed shrew, Blarina brevicauda, in eastern Nebraska have resulted in noteworthy records of several other species of small mammals. These field studies, which were supported by a grant from the Kansas Academy of Science, entailed extensive trapping of prairie habitats in Cass County, aproximately 15 miles west of the Missouri River. In addition to the species discussed below, specimens of Reithrodontomys megalotis, Peromyscus maniculatus, P. leucopus, and Mus musculus were obtained at several localities. All catalogue numbers in the following accounts refer to specimens deposited in the Museum of Natural History, The University of Kansas.

Sorex cinereus haydeni Baird, 1858.--For masked shrews collected 23-24 November 1968 provided the first localities of record for the species in Cass County: $4 / 10 \mathrm{mi}$. N and $2 \mathrm{mi}$. W Weeping Water (117849); 3/10 mi. S and $2 \mathrm{mi}$. W Weeping Water (117850); $1 \mathrm{mi} . \mathrm{S}$ and 2 mi. W Weeping Water (117851); 2 mi. S Weeping Water (117852). These localities are near the southern limit of the known geographic distribution of $S$. cinereus in Nebraska (Choate and Genoways, Trans. Kansas Acad. Sci., 69:238-239, 1966). One of the four specimens was in the process of completing autumnal molt, whereas the others already were in winter pelage.

Jones (Univ. Kansas Publ., Mus. Nat. Hist., 16:63, 1964) remarked that although $S$. cinereus frequently occurs in the same habitats in Nebraska as does the short-tailed shrew, Blarina brevicauda, he knew of no instance in which masked shrews had been collected in association with least shrews, Cryptotis parva. It is of interest, therefore, that all three species were obtained in the same trapline in apparently similar habitats at three localities near Weeping Water. At all three places, traps were set along a highway right-of-way where brome grass and a few forbs comprised the dominant vegetation.

Transactions of the Kansas Academy of Science, Vol. 73, No. 1, 1970. Published November 30, 1970. 
Cryptotis parva parva (Say, 1823).-Ten least shrews collected on 23-24 November 1968 constitute the first record of occurrence of the species in Cass County as follows: $2 \mathrm{mi}$. $\mathrm{N}$ and $2 \mathrm{mi}$. W Weeping Water (117853-54); $1 \mathrm{mi}$. $\mathrm{N}$ and $2 \mathrm{mi}$. W Weeping Water (117855); 4/10 mi. $\mathrm{N}$ and $2 \mathrm{mi}$. W Weeping Water $(117856-60) ; 3 / 10 \mathrm{mi} . \mathrm{S}$ and 2 mi. W Weeping Water (117861); $1 \mathrm{mi}$. S and $2 \mathrm{mi}$. W Weeping Water (117862). One young male had just begun the postjuvenal molt; all other individuals were in winter pelage. One adult male had testes that measured $2 \mathrm{~mm}$ in length.

Jones (op. cit.:71) rarely found $C$. parva to be common in Nebraska, and never obtained more than one specimen in the same trapline. Our trapping success would seem to indicate a relatively high local or seasonal abundance in Cass County, because 10 specimens were collected in only two nights, five in a single trapline. The short-tailed shrew, Blarina brevicauda, also was abundant at this time, as shown by the fact that 40 specimens were collected in two nights trapping.

Spermophilus tridecemlineatus tridecemlineatus (Mitchell; 1821).Three specimens collected on 29-30 June 1968 verify the presence of the thirteen-lined ground squirrel in Cass County, although the species is known from most of the surrounding counties and is a common inhabitant of eastern Nebraska. A subadult male (115933) from $1 / 2 \mathrm{mi}$. W Manley had testes measuring $2 \mathrm{~mm}$ in length; specimens from $2 \mathrm{mi}$. W Weeping Water include a subadult female (115934) and an adult male (115935), the latter having relatively small testes $(4 \mathrm{~mm})$.

Perognathus hispidus spilotus Merriam, 1889.-Two females (one lactating) hispid pocket mice caught on 30 June 1968, one (115926) from $2 \mathrm{mi}$. N and $2 \mathrm{mi}$. W Weeping Water and the other (115927) from $1 / 2 \mathrm{mi}$. W Manley, provide the first record of occurrence of the species in Cass County as well as the northeasternmost localities of record for the subspecies in Nebraska. Together with the ground squirrels and grasshopper mice reported herein, hispid pocket mice were collected in tall, native grass prairie interspersed with daisy fleabane and ragweed.

Onychomys leucogaster breviauritus Hollister, 1913.-A male and female (115940-41) obtained on 30 June 1968 at a place $1 / 2 \mathrm{mi}$. W Manley, together with a male (117903) caught on 23 November 1968 at a place $4 / 10 \mathrm{mi} . \mathrm{N}$ and $2 \mathrm{mi}$. W Weeping Water, constitute the first records of occurrence of the northern grasshopper mouse in Cass County as well as the easternmost localities of record for the species in Nebraska. It seems likely that grasshopper mice occur in suitable upland prairie 
habitats as far east in Nebraska as uplands bordering riparian communities of the Missouri River (see Jones, op. cit.:207-208).

Synaptomys cooperi gossii (Coues, 1877).-Four southern bog lemmings collected on 23-24 November 1968 provide the first localities of record for the species in Cass County-1 mi. $\mathrm{N}$ and $2 \mathrm{mi}$. W Weeping Water (117927), and 3/10 mi. S and $2 \mathrm{mi}$. W Weeping Water (11792830). Two of the four individuals were molting when captured.

Microtus ochrogaster ochrogaster (Wagner, 1842).-An adult female (117904) caught on 24 November 1968 at a place $2 \mathrm{mi}$. $\mathrm{N}$ and $2 \mathrm{mi}$. W Weeping Water constitutes the first locality record for the species in Cass County.

Microtus pennsylvanicus pennsylvanicus (Ord, 1815):-A total of 23 meadow voles was collected in Cass County as follows: $1 \mathrm{mi}$. $\mathrm{N}$ and 2 mi. W Weeping Water (117905-10, 117922-23); 4/10 mi. $\mathrm{N}$ and 2 mi. W Weeping Water $(117911-16) ; 2$ mi. W Weeping Water (115942); 3/10 mi. S and $2 \mathrm{mi}$. W Weeping Water (117917-21); $2 \mathrm{mi}$. $\mathrm{S}$ Weeping Water (117924-26). It is noteworthy that although the localities sampled are near the southern limit of the known geographic distribution of $M$. p. pennsylvanicus in Nebraska (Jones, op. cit.:228; Choate and Genoways, op. cit.:240-241), meadow voles were substantially more abundant than prairie voles, $M$. ochrogaster, in typical upland prairie in Cass County.

Only one of 13 females (at least eight adults) taken on 23-24 November 1968 was pregnant, containing six embryos (three in each horn of the uterus) that measured $20 \mathrm{~mm}$ in crown-rump length. Another female trapped at the same time had an enlarged uterus, but no placental scars were evident. One of seven adult males captured on 23-24 November had enlarged testes $(15 \mathrm{~mm})$, and three others had testes apparently in the process of regression $(4-7 \mathrm{~mm})$. The one male caught on 30 June 1968 had testes that measured $18 \mathrm{~mm}$ in length. Nine of 22 November-taken individuals were molting.

Zapus hudsonius pallidus Cockrum and Baker, 1950.-A lactating female (115943) caught on 30 June 1968 at a place $2 \mathrm{mi}$. $\mathrm{N}$ and $2 \mathrm{mi}$. W Weeping Water provides the second locality of record for the meadow jumping mouse in Cass County; the earlier record was from Weeping Water (Jones, op. cit.:241). 